\title{
Enhanced Phytostabilization of Metal-Contaminated Soil after Adding Natural Mineral Adsorbents
}

\author{
Maja Radziemska* \\ Warsaw University of Life Sciences, Faculty of Civil and Environmental Engineering Department \\ of Environmental Improvement, Nowoursynowska 159, 02-776 Warsaw, Poland
}

Received: 28 April 2017

Accepted: 19 June 2017

\begin{abstract}
A major challenge that we currently face regards protecting the natural environment from the negative effects of heavy metals. Aided phytostabilization is among the successfully developing techniques used to immobilize heavy metals in contaminated soils. Using pot experiments, this study evaluated the potential application of natural mineral adsorbents as immobilizing agents in the aided phytostabilization of $\mathrm{Zn}$-contaminated soil cultivated with Festuca rubra L. The research aimed to determine the influence of $\mathrm{Zn}$ in doses of 0 (control), 200, 400, and $600 \mathrm{mgkg}^{-1}$ of soil, as well as chalcedonite and dolomite amendments on the content of $\mathrm{Zn}$ in the above-ground parts and roots of F. rubra. $\mathrm{Zn}$ contents in the tested parts of F. rubra differed significantly in the case of applying chalcedonite and dolomite to the soil, as well as increasing concentrations of $\mathrm{Zn}$. The application of dolomite to soil contaminated with $\mathrm{Zn}$ contributed to a significant increase in $\mathrm{pH}$ values, and turned out to be most effective when it came to reducing total Zn content.
\end{abstract}

Keywords: aided phytostabilization, chemical properties of soil, risk minimization, mineral adsorbents

\section{Introduction}

A significant factor contributing to the degradation of the natural environment comes in the form of chemical elements released during various processes connected with anthropogenic activity [1]. The negative impact of humans on plants is observed, above all, in urban, industrial and agricultural areas. As an effect of the strong intervention of humans in shaping the soil profile, farreaching changes in the physicochemical properties of soils occur [2]. Therefore, it is important to look for new

*e-mail: maja_radziemska@sggw.pl solutions in the remediation of endangered areas, among which biological methods have been gaining increasing importance. Numerous scientific studies have shown that certain plant species, due to their specific features, have the ability to take up and degrade xenobiotics contaminating the environment [3-4]. Phytoremediation is a promising and intensively developing technique of cleaning the environment. Due to the means by which plants influence the decontamination of polluted ecosystems, a few types of this technique can be distinguished: phytoextraction, phytostabilization, phytodegradation, rhyzofiltration, and rhizostabilization [4].

Aided phytostabilization is a technique initiated in the last decade, based on applying soil additives that 
immobilize metals along with specially selected plant species. The main aim of phytostabilization is decreasing the risk of metals entering the food chain by limiting their capture by plants and decreasing leaching as a result of erosion and surface runoff [4]. Aided phytostabilization, on the other hand, relies on applying plants and soil additives for the physical stabilization of soil as well as the chemical immobilization of contaminants. Mineral sorption materials can be successfully applied as effective soil additives aiding the above-mentioned technique [67]. Plant species undergoing phytostabilization lower the bioavailability of toxic substances in the soil by emitting compounds (e.g., phenolic compounds, phytosiderophores, organic acids) into the rhizosphere [8]. Various grass species, including red fescue (Festuca rubra L.), turned out to be the most useful in the phytostabilization of heavy metals in soils [9].

In connection with the above, studies were assumed whose aim was to determine the influence of chalcedonite and dolomite applied to soil contaminated with $\mathrm{Zn}$ on the effectiveness of the process of aided phytostabilization by determining mobility and redistribution of $\mathrm{Zn}$ on Festuca rubra L., the concentration of $\mathrm{Zn}$ in soil, and determining bioconcentration (BCF) and translocation (TF) factors. Carrying out pilot studies under conditions of a pot experiment will make it possible to identify the mechanisms of soil contamination with $\mathrm{Zn}$ and enable the technique of aided phytostabilization to be optimized prior to its practical application in situ.

\section{Material and Methods}

\section{Plant Growth Experiment}

The greenhouse experiment was carried out in $5.0 \mathrm{~kg}$ polyethylene (PCV) pots containing soil contaminated with $\mathrm{Zn}$, amended with chalcedonite and dolomite, and vegetated with F. rubra (cv. Dark) plants. Simulated soil contamination with $\mathrm{Zn}$ was introduced in the following doses (mgkg-1 of soil): 0 (control), 200, 400, and 600 , with the soil also fertilized with a macro- and micronutrient fertilizer mixture. The soil, obtained from the surface layer of a non-contaminated site in an agricultural area, was air-dried and sieved through a $2 \mathrm{~mm}$ mesh screen. Physico-chemical properties of the soils included: $\mathrm{pH}$ 5.03; hydrolytic acidity $\left(\mathrm{mmol} \mathrm{kg}^{-1}\right) 33.24$; sum of exchangeable bases $\mathrm{Ca}^{2+}, \mathrm{Mg}^{2+}$, $\mathrm{K}^{+}, \mathrm{Na}^{+}\left(\mathrm{mmol} \mathrm{kg}^{-1}\right)$ 62.10; cation exchange capacity $\left(\mathrm{mmol} \mathrm{kg}^{-1}\right)$ 93.20, base saturation (\%) 64.20, total $\mathrm{N}\left(\mathrm{gkg}^{-1}\right) 1.13$, organic carbon $\left(\mathrm{g} \cdot \mathrm{kg}^{-1}\right)$ 7.12, $\mathrm{N}-\mathrm{NH}_{4}^{+}$ $\left(\mathrm{mgkg}^{-1}\right)$ 22.11, N-NO ${ }_{3}^{-}\left(\mathrm{mgkg}{ }^{-1}\right)$ 11.12, extractable $\mathrm{P}\left(\mathrm{mgkg}^{-1}\right) 33.20$, extractable $\mathrm{K}\left(\mathrm{mg} \mathrm{kg}^{-1}\right)$ 7.62, extractable $\mathrm{Mg}\left(\mathrm{mg} \mathrm{kg}^{-1}\right)$ 33.12, and $\mathrm{Zn}\left(\mathrm{mgkg}^{-1}\right)$ 24.12. The soil samples were thoroughly mixed and allowed to stabilize under natural conditions for three weeks before being used in the growth experiment. Two natural mineral-based amendments, i.e., chalcedonite, and dolomite, were mixed in with the soil in the amount of 3.0\% (each). Soils without
$\mathrm{Zn}$ and amendments $(0.0 \%)$ were designated as the control. The experiment was assessed with three replications. The plants were watered every other day with distilled water to $60 \%$ of the maximum water-holding capacity of the soil by adding deionized water. They were harvested after 46 days (at the shooting stage), and the soil was collected.

\section{Characteristics of Amendments}

Chalcedonite is a siliceous rock found mainly in volcanic rocks. Among the many places that this mineral appears throughout the world (e.g., Brazil, India, Kazakhstan, Slovakia, and Germany), it can be found in Poland, among others, in the area of Złotoryja, Wałbrzych, and Inowłódz. Dolomite is a calcium and magnesium carbonate created in natural conditions. The mineral crystals are colourless, but depending on the types of additives, can take on other colours. Dolomite rocks are widespread throughout the world, including in Poland. They create geological formations, e.g. the Alps. In Poland, they are found mainly in Upper and Lower Silesia, near Chrzanow, Jelenia Góra, and Złoty Stok. Both minerals are commonly used in many fields, including industry, construction, and environmental engineering, but have not, as of yet, been applied as a means of aiding the technique of phytostabilization. Sorbents used in this experiment are characterized by their properties causing soil $\mathrm{pH}$ increase, which is one of the main mechanisms in the phytostabilization technique.

Chalcedonite was purchased from Chalcedon Poland (Inowłódz, Poland), and dolomite from Dolomite Mines S.A. (Sandomierz, Poland). Scanning electron microscope (SEM) images of amendments and their chemical compositions are shown in Fig. 1.

\section{Evaluating Soil}

Before setting up the experiment, the following soil properties were determined: soil $\mathrm{pH}$ measured in a suspension of 1:2.5 soil-to-water by a digital $\mathrm{pH}$-meter; electrical conductivity (EC), measured with a Handylab pH/LF 12 conductometer (Schott, Germany), in a 1:2 soil/deionized water suspension (w/v); hydrolytic acidity (HAC) by Kappen's method, with soil samples treated with $0.5 \mathrm{M} \cdot \mathrm{dm}^{-3} \mathrm{Ca}$-acetate solution adjusted to a $\mathrm{pH}$ of 8.2 in the ratio of 1:2.5 [10]; total exchangeable bases (TEB-K $\mathrm{K}^{+}, \mathrm{Na}^{+}, \mathrm{Ca}^{2+}$, and $\mathrm{Mg}^{2+}$ ) by Kappen's method through determining individual cations after extraction from the soil with $\mathrm{CH}_{3} \mathrm{COONH}_{4}$ [10]; cation exchange capacity (CEC) from the formula $\mathrm{CEC}=\mathrm{HAC}+\mathrm{TEB}$, and percentage base saturation $(\mathrm{V})$ from the formula $\mathrm{BS}=100$. $\mathrm{TEB} / \mathrm{CEC}^{-1}$; organic matter according to Tiurin's method; $\mathrm{P}$ and $\mathrm{K}$ content according to the Egner-Riehm method [11]; and $\mathrm{Mg}$ content according to the atomic absorption spectrometry method following extraction using the Schachtschabel method [12]. A modified version of the EPA 3051A method was used in the digestion of soils. Briefly, $1.0 \mathrm{~g}$ of soil was weighed in a vessel and $9 \mathrm{~mL}$ of nitric acid with a concentration of $1.40 \mathrm{gcm}^{-1}$, and $1 \mathrm{~mL}$ of 


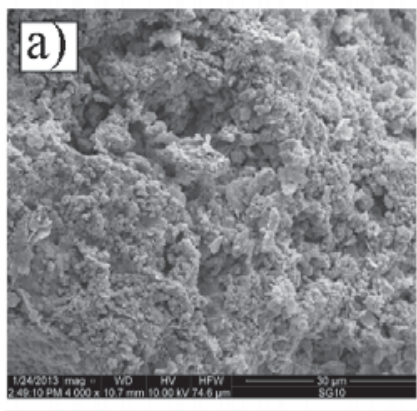

$\mathrm{SiO}_{2}-84.77 \% ; \mathrm{Al}_{2} \mathrm{O}_{5}-9.33 \%$ $\mathrm{C}_{2} \mathrm{O}-4.29 \% ; \mathrm{K}_{2} \mathrm{O}-1.21 \%$; $\mathrm{MgO}-0.40 \%$

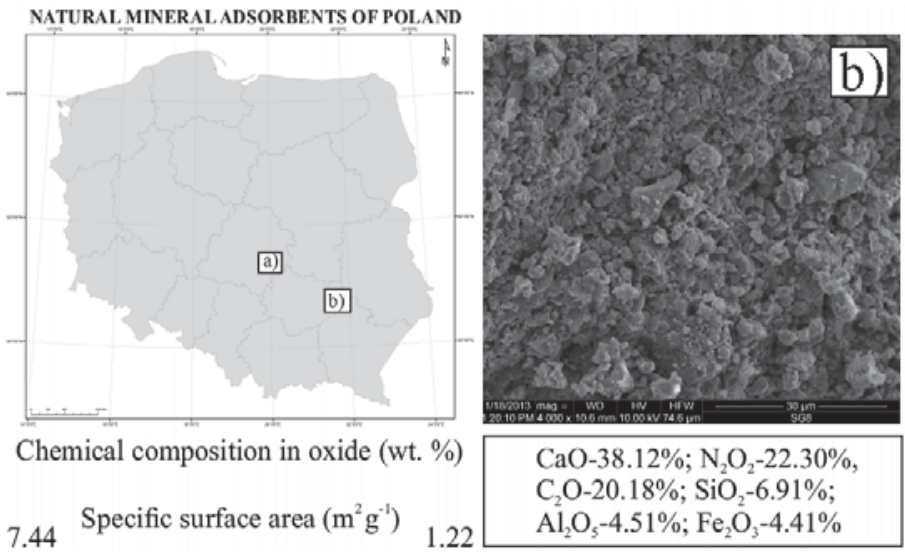

Fig. 1. Location of naturally occurring mineral adsorbents of Poland, SEM images and chemical composition of chalcedonite a) and dolomite b).

a $30 \% \mathrm{H}_{2} \mathrm{O}_{2}$ (Chempur, Poland) was added. The digestions were carried out in a Milestone microwave oven (Start $\mathrm{D}$, Italy). After filtration, the digestion products were adjusted to $100 \mathrm{~mL}$ volume with deionized water. The concentrations of $\mathrm{Zn}$ in the diluted extracts were measured by means of atomic absorption spectrometry (AAS) using an iCE-3000 spectrophotometer (Thermo Scientific, USA). Triplicates were performed for each sample.

\section{Plant Analysis}

At the end of the experiment, the plants were harvested and the roots and shoots separated, washed with tap water, and rinsed with distilled water. Dry weight was measured after drying the plants in an oven at $105^{\circ} \mathrm{C}$ for $24 \mathrm{~h}$. The dried samples were ground in a mill (Retsch type ZM 300, Hann, Germany) and then stored at $4^{\circ} \mathrm{C}$ protected from light in clean polyethylene containers for later chemical analysis. Zn was determined by atomic absorption spectrometry (AAS) using an iCE-3000 spectrophotometer (Thermo Scientific, USA). Triplicates were performed for each sample. All reagents were of analytical reagent grade unless otherwise stated. Stock solutions of metals $\left(1000 \mathrm{mg} \cdot \mathrm{L}^{-1}\right)$ were prepared from their nitrate salts. Ultrapure water (Millipore System, USA) of $0.055 \mu \mathrm{Scm}^{-1}$ resistivity was used for preparing the solutions and dilutions. All glass and polyethylene flaskware had been previously treated for 24 hours in $5 \mathrm{~mol} \cdot \mathrm{L}^{-1} \mathrm{HNO}_{3}$ and then rinsed with ultrapure water.

\section{Calculations and Statistical Analyses}

The bioconcentration coefficient $\left(\mathrm{BCF}_{\text {roots }}\right)$ and translocation factor (TF) were used to understand the capability of $\mathrm{Zn}$ to accumulate in the roots of Festuca rubra L. and translocate to aboveground parts of the plant, and were calculated as follows: $\mathrm{BCF}_{\text {roots }}=\mathrm{Zn}$ concentration in roots/Zn concentration in soil, and $\mathrm{TF}=\mathrm{Zn}$ concentration in aboveground parts/Zn concentration in roots [13].

All treatments were replicated three times. The means and standard deviations $( \pm \mathrm{SD})$ were calculated using
Microsoft Office Excel 2010. Statistical analyses of results were performed using the Statistica program, v. 10.0.

\section{Results and Discussion}

\section{Biomass Response of F. rubra to Zn Contamination and Application of Amendments}

The results of earlier experiments show a metal immobilizing effect on plant biomass after the application of mineral sorbents (i.e., halloysite, zeolite, limestone, and calcium oxide) in pot experiments [14-15]. The results showed that the growth of the tested plant was signifi-cantly affected by the dose of the Zn-contaminant and the applied amendments. The effects of chalcedonite and dolomite on the biomass production of F. rubra grown in $\mathrm{Zn}$-contaminated soils are shown in Fig 2. A concentration of $\mathrm{Zn}$ in soil of $600 \mathrm{mgkg}^{-1}$ significantly decreased (nearly fourfold) the biomass of F. rubra.

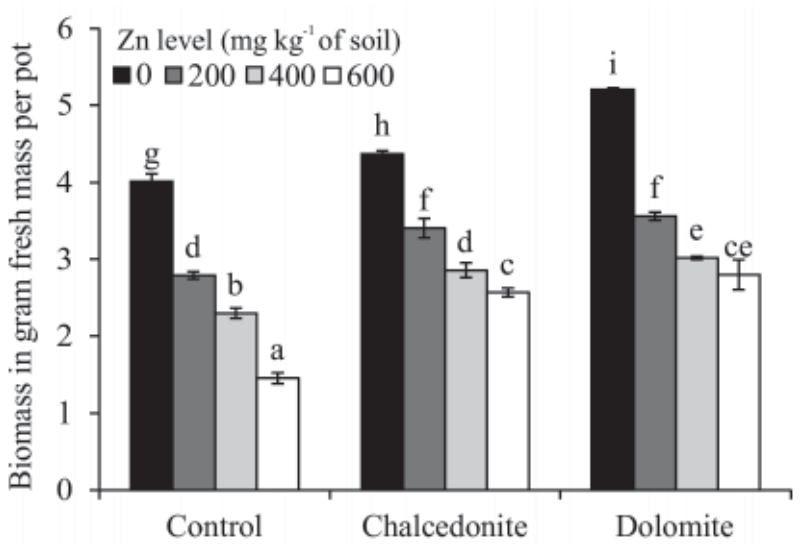

Fig. 2. Effect of zinc contamination, chalcedonite, and dolomite on the aboveground biomass of Festuca rubra L. in grams of fresh mass per pot. Error bars are \pm standard error $(n=3)$. Bars marked with different letters differ significantly for the same $\mathrm{Zn}$ exposure $(\mathrm{P}<0.05)$ according to the Duncan test. 
As reported by Yadav [16], Zn at high soil concentrations $\left(150\right.$ to $\left.300 \mu \mathrm{gg}^{-1}\right)$ is strongly toxic to plants, while its phytotoxicisty is largely dependent on the plant species as well as the plant development stage [17-18]. $\mathrm{Zn}$ contamination in Populus alba drastically changed leaf morphology and ultrastructure [19]. Vijayarengan and Mahalakshmi [20], in turn, showed that Zn toxicity decreased the length of the roots and shoot, as well as the area of the leaves in Solanum lycopersicum L. A visual symptom of problems resulting from the toxic effect of $\mathrm{Zn}$ in plants is the chlorosis of young leaves caused by Mn deficiency [21]. In the carried out study, F. rubra did not show any visible symptoms of Zn toxicity or nutrient deficiency when grown on the contaminated soil with amendments. The greatest average aboveground biomass was observed in cases of amending soil with chalcedonite (38\%) as compared to not applying any of these substances to the soil. Dolomite also had a positive, though lesser, influence. In another experiment conducted by Radziemska et al. [22, 3], chalcedonite and halloysite added to soil contaminated with heavy metals caused an increase in L. perenne and B. juncea biomass. Moreover, Wyszkowski and Radziemska [15, 23] confirm that zeolite increased the average yield of plants (oat, spring barley, and maize) grown on soil polluted with $\mathrm{Cr}(\mathrm{VI})$. Areas contaminated with heavy metals generally represent a low level of plant cover growth, and deprived of vegetation, soils are prone to erosion and leaching, which can lead to the movement of heavy metals to further components of the natural environment. This supports the application of methods of aided phytostabilization, while the use of mineral sorbents has a significant positive effect on the amount and quality of plant cover as has been proven by studies.

\section{Zn Accumulation and Translocation of F. rubra}

$\mathrm{Zn}$ is an element that is considered to be essential for proper plant growth and development as it is a component of many enzymes and, moreover, takes part in carbohydrate, protein, and phosphate metabolism [24]. Deficiencies as well as excessive amounts of this element can have a negative effect on plants, with the line between its deficiency and toxicity being very easy to cross. With an increase in the $\mathrm{Zn}$ concentration of soil, $\mathrm{Zn}$ accumulation increased in all parts of the F. rubra, with the content in the roots being much higher than in the shoots (Fig. 3). In the control, $\mathrm{Zn}$ concentrations (in $\mathrm{mg} \mathrm{kg}{ }^{-1}$ dry weight) varied between 60.42 and 201.27 in the shoots, and between 68.09 and 226.64 in the roots. Data found in literature confirm the existence of a correlation between total $\mathrm{Zn}$ content in soil and its concentration in plants [25-27]. $\mathrm{Zn}$ in its divalent state $\left(\mathrm{Zn}^{2+}\right)$ is the most pervasive form found in soil and most available to plants [28]. The present research reveals that the application of chalcedonite and dolomite had an influence on the average $\mathrm{Zn}$ content in F. rubra. The highest reduction of $\mathrm{Zn}$ contents $(20 \%)$ was observed in the aboveground parts of the tested plant

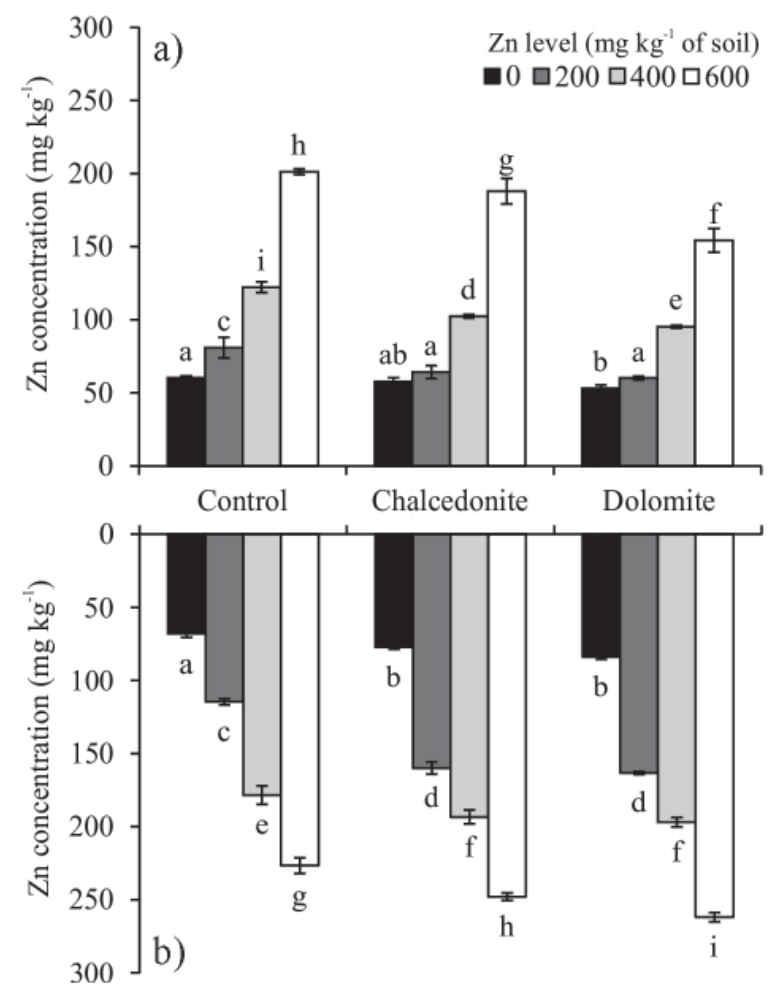

Fig. 3. Zinc concentration ( $\mathrm{mg} \cdot \mathrm{kg}^{-1}$, dry weight basis) in the aboveground parts (A) and roots (B) of Festuca rubra L. at the end of the trial. Error bars are \pm standard error $(n=3)$. Bars marked with different letters differ significantly for the same $\mathrm{Zn}$ exposure $(\mathrm{P}<0.05)$ according to the Duncan test.

species grown in soil containing dolomite, as compared to the uncontaminated soil. These results were similar to another experiment conducted by Radziemska et al. [3, 14, $29]$, where the heavy metal contents in the aboveground parts of $Z$. mays, $B$. juncea, and $L$. perenne were affected by the application of mineral sorbents (i.e., zeolite, halloysite, limestone, chalcedonite, and dolomite). The roots of the test plat contained $22 \%$ more $\mathrm{Zn}$ as compared to the control group when dolomite was applied to the soil.

Plant species suitable for phytostabilization should be characterized by a $\mathrm{BCF}>1$ and $\mathrm{TF}<1$ [3]. The results obtained for $\mathrm{BCF}_{\text {roots }}$ and TF are shown in Table 1. The highest values of the $\mathrm{BCF}_{\text {roots }}$ for $\mathrm{Zn}$ were observed for dolomite treatment. TF, on the other hand, was $<1$ for all series of the experiment, assuming the lowest value also in the case of treatment with dolomite. In an experiment by Abad-Valleet et al. [30] where sepiolite was added to soil contaminated with heavy metals, TF values for F. rubra varied from 0.058 to 0.065 .

\section{Soil Properties after Applying Amendments}

Soil $\mathrm{pH}$ is one of the most important factors directly influencing the bioavailability of metals and their take up by the roots of plants [31]. Soils with a neutral $\mathrm{pH}$, as compared to acidic soils, bind much higher amounts of heavy metals, while these metals are less soluble 
Table 1. Effects of applying chacedonite and dolomite on $\mathrm{Zn}$ accumulation $\left(\mathrm{BCF}_{\text {roots }}\right)$ and translocation (TF) factors in F. rubra (grown in Zn-contaminated soil).

\begin{tabular}{|c|c|c|c|c|c|c|}
\hline \multirow{2}{*}{$\begin{array}{l}\text { Dose } \mathrm{Zn} \mathrm{mg} \cdot \mathrm{kg}^{-1} \\
\text { of soil }\end{array}$} & \multicolumn{3}{|c|}{$\mathrm{BCF}_{\text {roots }}$} & \multicolumn{3}{|c|}{$\mathrm{TF}$} \\
\hline & Control & Chalcedonite & Dolomite & Control & Chalcedonite & Dolomite \\
\hline 0 & 1.69 & 2.02 & 2.69 & 0.89 & 0.75 & 0.63 \\
\hline 200 & 1.61 & 1.97 & 1.05 & 0.71 & 0.40 & 0.37 \\
\hline 400 & 1.53 & 1.62 & 1.64 & 0.69 & 0.53 & 0.48 \\
\hline 600 & 1.52 & 1.62 & 1.66 & 0.79 & 0.61 & 0.59 \\
\hline
\end{tabular}

compounds, as a result of which they are less available to plants. The total content of heavy metals in the soil is, in addition to $\mathrm{pH}$, one of the most important factors influencing the absorption of heavy metals and their content in a plant. High levels of heavy metals in the soil restrict the uptake of micro- and macroelements, as well as preventing the movement of ions necessary for proper metabolism, such as $\mathrm{Ca}, \mathrm{Mg}, \mathrm{Fe}, \mathrm{P}$, and $\mathrm{Zn}$ from the roots to the shoots [3]. In the presented research, the $\mathrm{pH}$ of soil solutions increased following the addition of mineral sorbents (control $5.62 \pm 0.10$, chalcedonite $6.12 \pm 0.06$, and dolomite $7.02 \pm 0.12$ ). In the series lacking mineral additives, increasing doses of contamination caused a successive increase in the $\mathrm{pH}$ of soil. The greatest increase was $1.40 \mathrm{pH}$ units, observed after dolomite was added to the soil. The studies of Shaheen and Rinklebe [32] showed that alkaline substances are more useful when used as substances neutralizing the acidity of soil, caused by the introduction of additives, e.g., organic ones. Wang et al. [33] reported that availability of $\mathrm{Zn}$ to the roots of Thlaspi caerulescens decreased with increases in soil $\mathrm{pH}$. Total $\mathrm{Zn}$ concentrations in soil depend on the dosage of soil contaminants and the type of amendments added (Fig. 4). The application of dolomite led to a significant decrease in $\mathrm{Zn}$ concentrations in soil as compared to the control pots. In an earlier experiment conducted by Radziemska and Mazur [22], the addition of zeolite,

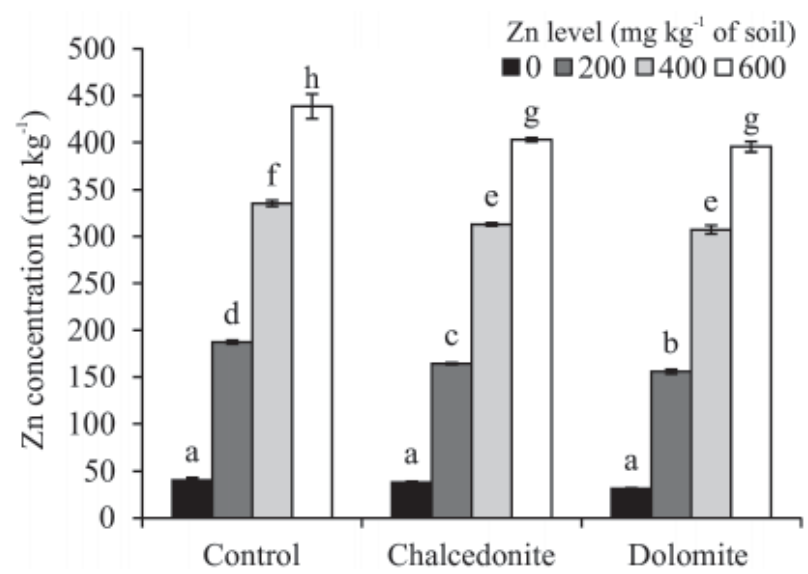

Fig. 4. $\mathrm{Zn}$ concentrations in soil with the different soil treatments (mean $\pm \mathrm{SD}, \mathrm{n}=3$ ). Values in columns marked with the same letter do not differ significantly (Duncan test, $\mathrm{P}>0.05$ ). halloysite, diatomite, and limestone to soil contaminated with heavy metals caused a significant decrease of $\mathrm{Zn}$ in the soil.

\section{Conclusions}

Contamination of soil by heavy metals, including $\mathrm{Zn}$, poses a real threat to the safety of food and the public, and is now emerging as a major health hazard to humans and plants. The present study clearly showed that soil phytostabilization techniques can be useful for alleviating the adverse effects of $\mathrm{Zn}$ deposition in the food chain. Natural mineral adsorbents such as chalcedonite and dolomite have great advantages in the aided phytostabilization of Zn-polluted soils, including high performance, universal applicability, and simplicity of use. The efficiency of phytostabilization depends on the plant species and soil amendments used. The best amendments are: not toxic to plants, easy to handle and produce, inexpensive, and, most importantly, safe for workers who apply them. In the presented research, the greatest average above-ground biomass of F. rubra was observed in cases of amending soil with chalcedonite. $\mathrm{Zn}$ accumulated in the roots, thereby reducing its toxicity to the aerial parts of the plant. The application of dolomite to soil contaminated with $\mathrm{Zn}$ contributed to a significant increase in $\mathrm{pH}$ values and turned out to be most effective when it came to reducing total $\mathrm{Zn}$ content. It should be stated that the positive results of the carried out pot experiment should next be implemented in a field experiment and their longterm effects monitored.

\section{References}

1. VAVERKOVA M., ADAMCOVA D. Heavy metals uptake by select plant species in the landfill area of Stepanovice, Czech Republic. Polish Journal of Environmental Studies, 23 (6), 2265, 2014

2. GWOREK B., DMUCHOWSKI W., KODA E., MARECKA M., BACZEWSKA A.H., BRĄGOSZEWSKA P., SIECZKA A., OSIŃSKI P. Impact of the municipal solid waste Łubna Landfill on environmental pollution by heavy metals. Water, 8 (10), 470, 2016.

3. WYSZKOWSKI M., RADZIEMSKA M. Assessment of tri- and hexavalent chromium phytotoxicity on Oats (Avena 
sativa L.) biomass and content of nitrogen compounds. Water Air and Soil Pollution, 244, 1619-1632, 2013.

4. ZHANG M., FANG T., PU G., SUN X., ZHOU X., CAI Q. Xenobiotic metabolism of plant secondary compounds in the English grain aphid, Sitobion avenae (F.) (Hemiptera: Aphididae). Pesticide Biochemistry and Physiology, 7 (1), 44, 2013.

5. LABIDI S., FIRMIN S., VERDIN A., BIDAR G., LARUELLE F., DOUAY F., SHIRALI P., FONTAINE J., SAHRAOUI A.L.H. Nature of fly ash amendments differently influences oxidative stress alleviation in four forest tree species and metal trace element phytostabilization in aged contaminated soil: A long-term field experiment. Ecotoxicology and Environmental Safety, 138, 190, 2017.

6. RADZIEMSKA M., MAZUR Z., JEZNACH J. Influence of applying halloysite and zeolite to soil contaminated with nickel on the content of selected elements in Maize (Zea mays L.). Chemical Engineering Transactions, 32, 301, 2013.

7. LI Z., ZHU W., GUO X. Effects of combined amendments on growth and heavy metal uptake by Pakchoi (Brassica chinensis L.) planted in Contaminated soil. Polish Journal of Environmental Studies, 24 (6), 2493, 2015.

8. LI Y., WANG Q., WANG L., HE L.Y., SHENG X.F. Increased growth and root $\mathrm{Cu}$ accumulation of Sorghum sudanense by endophytic Enterobacter sp. K3-2: Implications for Sorghum sudanense biomass production and phytostabilization. Ecotoxicology and Environmental Safety, 124, 163, 2016

9. GAJIĆ G., DJURDJEVIĆ L., KOSTIĆ O., JARIĆ S., MITROVIĆ M., STEVANOVIĆ B., PAVLOVIĆ P. Assessment of the phytoremediation potential and an adaptive response of Festuca rubra L. sown on fly ash deposits: Native grass has a pivotal role in ecorestoration management. Ecological Engineering, 93, 250, 2016.

10. KLUTE A. Methods of soil analysis. Madison: American Society of Agronomy. Agronomy Monograph, 9, 1996.

11. RIEHM H. The ammonium lactate acetic acid method for determination of soluble phosphorous acid in soil." Agrochimica, 3, 49, 1958 [In German].

12. LITYŃSKI T., JURKOWSKA H., GORLACH E. Chemical and agriculture analysis. PWN, Warsaw, 129, 1976 [in Polish].

13. LIANG S.X., JIN Y., LIU W., LI X., SHEN S.G., DING $\mathrm{L}$. Feasibility of $\mathrm{Pb}$ phytoextraction using nano-materials assisted ryegrass: Results of a one-year field-scale experiment. Journal of Environmental Management, 190, 170, 2017.

14. RADZIEMSKA M., MAZUR Z., FRONCZYK J., MATUSIK J. Co-remediation of Ni-contaminated soil by halloysite and Indian mustard (Brassica juncea L.).Clay Minerals, 51, 489, 2016.

15. WYSZKOWSKI M., RADZIEMSKA M. Effects of chromium (III and VI) on spring barley and maize biomass yield and content of nitrogenous compounds. Journal of Toxicology and Environmental Health, Part A, 73, 1274, 2010.

16. YADAV S.K. Heavy metals toxicity in plants: an overview on the role of glutathione and phytochelatins in heavy metal stress tolerance of plants. South African Journal of Botany, 76, 167, 2010.

17. AMARI T., GHNAYA T., ABDELLY C. Nickel, cadmium and lead phytotoxicity and potential of halophytic plants in heavy metal extraction. South African Journal of Botany, 111, 99, 2017.
18. XIAO R., SUN X., WANG J., FENG J., LI R., ZHANG Z., WANG J.J., AMJAD A. Characteristics and phytotoxicity assay of biochars derived from a Zn-rich antibiotic residue. Journal of Analytical and Applied Pyrolysis, 113, $575,2015$.

19. TODESCHINI V., LINGUA G., D'AGOSTINO G., CARNIATO F., ROCCOTIELLO E., BERTA G. Effects of high zinc concentration on poplar leaves: a morphological and biochemical study. Environmental and Experimental Botany, 71 (1), 50, 2011.

20. VIJAYARENGAN P., MAHALAKSHMI G. Zinc toxicity in tomato plants. World Applied Sciences Journal, 24 (5), 649, 2013.

21. NAVARRO-LEÓN E., ALBACETE A., TORREGONZÁlEZ A., RUIZ J.M., BLASCO B. Phytohormone profile in Lactuca sativa and Brassica oleracea plants grown under Zn deficiency. Phytochemistry, 130, 85, 2016.

22. RADZIEMSKA M., MAZUR Z. Content of selected heavy metals in Ni-contaminated soil following the application of halloysite and zeolite. Journal of Ecological Engineering, 17 (3), 125, 2016.

23. WYSZKOWSKI M., RADZIEMSKA M. Influence of chromium (III) and (VI) on the concentration of mineral elements in oat (Avena sativa L.). Fresenius Environmental Bulletin, 22 (4), 979, 2013.

24. VENKATACHALAM P., PRIYANKA N., MANIKANDAN K., GANESHBABU I., INDIRAARULSELVI P., GEETHA N., MURALIKRISHNA K. Enhanced plant growth promoting role of phycomolecules coated zinc oxide nanoparticles with P supplementation in cotton (Gossypium hirsutum L.). Plant Physiology and Biochemistry, 110,118, 2017.

25. BŘENDOVÁ K., ZEMANOVÁ V., PAVLÍKOVÁ D., TLUSTOŠ P. Utilization of biochar and activated carbon to reduce $\mathrm{Cd}, \mathrm{Pb}$ and $\mathrm{Zn}$ phytoavailability and phytotoxicity for plants. Journal of Environmental Management, 181, 637, 2016.

26. FERNÁNDEZ S., POSCHENRIEDER C., MARCENÒ C., GALLEGO J.R., JIMÉNEZ-GÁMEZ D., BUENO A., AFIF E. Phytoremediation capability of native plant species living on $\mathrm{Pb}-\mathrm{Zn}$ and $\mathrm{Hg}$-As mining wastes in the Cantabrian range, north of Spain. Journal of Geochemical Exploration, 174, 10, 2017.

27. PUSCHENREITER M., GRUBER B., WENZEL W.W., SCHINDLEGGER Y., HANN S., SPANGL B., WALTER SCHENKEVELD D.C., KRAEMER S.M., OBURGER E. Phytosiderophore-induced mobilization and uptake of $\mathrm{Cd}$, $\mathrm{Cu}, \mathrm{Fe}, \mathrm{Ni}, \mathrm{Pb}$ and $\mathrm{Zn}$ by wheat plants grown on metalenriched soils. Environmental and Experimental Botany, 138, 67, 2017.

28. TRIPATHI D.K., SINGH S.S., SINGH S., PANDEY R., SINGH V.P., SHARMA N.C., PRASAD S.M., DUBEY N.K., CHAUHAN D.K. An overview on manufactured nanoparticles in plants: Uptake, translocation, accumulation and phytotoxicity. Plant Physiology and Biochemistry, 110, 2, 2017.

29. RADZIEMSKAM., MAZUR Z., FRONCZYK J., JEZNACH J. Effect of zeolite and halloysite on accumulation of trace elements in maize (Zea Mays L.) in nickel contaminated soil. Fresenius Environmental Bulletin, 23 (12a), 3140, 2014

30. ABAD-VALLE P., ÁlVAREZ-AYUSO E., MURCIEGO A., PELLITERO E. Assessment of the use of sepiolite amendment to restore heavy metal polluted mine soil. Geoderma, 280, 57, 2016. 
31. REIJONEN I., HARTIKAINEN H. Oxidation mechanisms and chemical bioavailability of chromium in agricultural soil $-\mathrm{pH}$ as the master variable. Applied Geochemistry, 74, 84, 2016.

32. SHAHEEN S.M., RINKLEBE J. Impact of emerging and low cost alternative amendments on the (im)mobilization and phytoavailability of $\mathrm{Cd}$ and $\mathrm{Pb}$ in a contaminated floodplain soil. Ecological Engeneering, 74, 319, 2015.
33. WANG A. S., ANGLE J. S., CHANEY R. L., DELORME T. A., REEVES R.D. Soil pH effects on uptake of $\mathrm{Cd}$ and $\mathrm{Zn}$ by Thlaspi caerulescens. Plant and Soil, 281 (1-2), 325, 2006. 